Активность системы негативной регуляции Т-клеточного ответа PD-1/PD-L1/PD-L2 у больных пневмониями на фоне гриппа A/H1N1

А. В. Малярчиков*, К. Г. Шаповалов, С. А. Лукьянов, П. П. Терешков, Л. С. Казанцева Читинская государственная медицинская академия Минздрава России, Россия, 672000, г. Чита, ул. Горького, д. 39А

\title{
Activity of Negative Regulation of the PD-1/PD-L1/PD-L2 T-Cell Response System in Patients with Pneumonia and Influenza A (H1N1)
}

\author{
Andrey V. Malyarchikov*, Konstantin G. Shapovalov, Sergey A. Lukyanov, \\ Pavel P. Tereshkov, Lyudmila S. Kazantseva \\ Chita State Medical Academy, Ministry of Health of Russia, \\ 39a Gorky Str., 672000 Chita, Russia
}

\begin{abstract}
Для цитирования: А. В. Малярчиков, К. Г. Шаповалов, С. А. Лукьянов, П. П. Терешков, Л. С. Казанцева. Активность системы негативной регуляции Т-клеточного ответа PD-1/PD-L1/PD-L2 у больных пневмониями на фоне гриппа A/H1N1. Общзая реаниматология. 2021; 17 (4): 4-11. https://doi.org/10.15360/1813-9779-2021-4-4-11 [На русск. и англ.]

For citation: Andrey V. Malyarchikov, Konstantin G. Shapovalov, Sergey A. Lukyanov, Pavel P. Tereshkov, Lyudmila S. Kazantseva. Activity of Negative Regulation of the PD-1/PD-L1/PD-L2 T-Cell Response System in Patients with Pneumonia and Influenza A (H1N1). Obshchaya Reanimatologiya = General Reanimatology. 2021; 17 (4): 4-11. https://doi.org/10.15360/18139779-2021-4-4-11 [In Russ. and Engl.]
\end{abstract}

\section{Резюме}

Системное воспаление является неотъемлемой патофизиологической составляющей многих критических состояний. В основе системного воспалительного ответа лежит каскад взаимодействий, приводящий к гиперцитокинемии, и, как следствие, к полиорганной недостаточности, которая является одной из основных причин летальности в отделениях интенсивной терапии.

Цель работы. Оценить активность системы негативной регуляции Т-клеточного ответа, определив плазменную концентрацию молекул PD-1, PD-L1 и PD-L2 у больных пневмониями на фоне гриппа A/H1N1.

Материалы и методы. Обследовали 85 больных пневмонией на фоне гриппа A/H1N1. Из них 30 пациентов с тяжелой пневмонией, 55 - с нетяжелой пневмонией. Методом проточной цитофлуометрии определяли плазменную концентрацию молекул PD-1, PD-L1, PD-L2.

Результаты. Установили, что у больных тяжелой пневмонией на фоне гриппа A/H1N1 плазменная концентрация рецептора PD-1 повышалась в 4,6 раза, при этом концентрация его лигандов PD-L1 и PD-L2 увеличивалась в 10,6 и в 2,2 раза, соответственно.

Заключение. Статистически значимое увеличение концентрации PD-1 и его лигандов PD-L1 и PD-L2 у больных пневмонией на фоне гриппа A/H1N1 свидетельствует о вовлечении в каскад иммунологических реакций системы негативной регуляции Т-клеточного ответа и ассоциировано с тяжестью состояния. Возможная коррекция иммунных реакций, реализуемых через комплекс PD-1/PD-L1/PD-L2 у пациентов в критическом состоянии - это перспективное научное направление.

Ключевые слова: PD-1; PD-L1; PD-L2; грипn A/H1N1; пневмония

Конфликт интересов. Авторы заявляют об отсутствии конфликта интересов.

\section{Summary}

Systemic inflammation is an integral pathophysiological component of many critical illnesses. The systemic inflammatory response is based on a cascade of interactions leading to hypercytokinemia and, as a consequence, multiple organ failure, which is one of the main causes of mortality in intensive care units.

Aim of the study. To evaluate the activity of the negative regulation system of T-cell response by determining the plasma levels of PD-1, PD-L1 and PD-L2 molecules in pneumonia patients with influenza A (H1N1).

Materials and methods. 85 patients with pneumonia and underlying influenza A (H1N1) were examined. Among them there were 30 patients with severe pneumonia, and 55 patients with non-severe pneumonia. Plasma levels of PD-1, PD-L1, PD-L2 molecules was determined by flow cytofluorometry method.

Адрес для корреспонденции:

Андрей Викторович Малярчиков*

E-mail: malyarchikov@bk.ru
Correspondence to:

Andrey V. Malyarchikov*

E-mail: malyarchikov@bk.ru 
Results. In patients with severe pneumonia and underlying influenza A (H1N1), the plasma level of PD-1 receptor increased 4.6-fold, while the concentration of its ligands PD-L1 and PD-L2 increased 10.6 and 2.2fold, respectively.

Conclusion. Significant increase in levels of PD- 1 and its ligands PD-L1 and PD-L2 in patients with pneumonia and underlying influenza A $(\mathrm{H} 1 \mathrm{~N} 1)$ indicates the involvement of negative regulation system of T-cell response in the cascade of immunological reactions and is associated with the severe disease. Possible correction of immune reactions realized through PD-1/PD-L1/PD-L2 complex in critically ill patients is a promising research avenue.

\section{Keywords: PD-1; PD-L1; PD-L2; influenza A (H1N1); pneumonia}

Conflict of interest. The authors declare no conflict of interest.

\section{Введение}

Системное воспаление является неотъемлемой патофизиологической составляющей многих критических состояний. Как известно, в основе системного воспалительного ответа лежит каскад взаимодействий, приводящий к гиперцитокинемии, что влечет за собой развитие про- и противовоспалительных реакций $[1,2]$. Современные подходы и методы интенсивной терапии позволяют пациентам в критическом состоянии преодолевать период преобладания гипервоспалительных реакций с дальнейшим переходом в фазу иммуносупрессии [1, 3]. Один из путей регуляции иммунного ответа активируется посредством связывания рецептора PD-1 с лигандом PD-L1/PD-L2. Programmed cell death-1 (PD-1) - ко-ингибирующий рецептор из системы негативной регуляции Т-клеточного ответа [3-5]. Ключевым механизмом иммуносупрессии является ингибирующее влияние PD-1 на T-клетки, что приводит к их истощению, что очень схоже с преждевременным клеточным старением, так как и стареющие, и истощенные Т-лимфоциты не экспрессируют белок CD28, из-за чего теряют способность к антигенной активации и не способны синтезировать цитокины [3, 5, 6]. Кроме того, взаимодействие PD-1 с лигандом PD-L1 способствует дифференцировке CD4+T-клеток в регуляторные FOXP3+ клетки, что оказывает влияние на продолжительность и силу иммунного ответа [3]. Иммуносупрессивная активность PD-1 связана также с ингибирующим воздействием на киназы, вовлеченные в активацию Т-клеток через фосфатазы SHP-1 и SHP-2, ингибируя, таким образом путь Т-клеточного рецептора (TCR) PI3K/AKT [5, 7, 8]. Молекула PD-L1 является лигандом для двух рецепторов - B7-1 (CD80) и PD-1 (CD279), экспрессируется на Т- и В-лимфоцитах, макрофагах, дендритных клетках, эндотелиальных, гемопоэтических и эпителиальных клетках [9]. Фактор PD-L2, относится к семейству белков B7, ограниченно экспрессируется на дендрит-

\section{Introduction}

Systemic inflammation is an integral pathophysiological component of many critical illnesses. The systemic inflammatory response is based on a cascade of interactions leading to hypercytokinemia, which entails the development of pro- and anti-inflammatory reactions $[1,2]$. Modern approaches and methods of intensive therapy allow critically ill patients to overcome the period of predominant hyperinflammation and further transition to immunosuppression [1,3]. One of the ways of immune response regulation includes activation of $\mathrm{PD}-1$ receptor binding to $\mathrm{PD}-\mathrm{L} 1 / \mathrm{PD}-\mathrm{L} 2$ ligand. Programmed cell death-1 (PD-1) is a co-inhibitory receptor, a component of the negative regulation of T-cell response system [3-5]. PD-L1/PD-L2 - PD1 interactions represent the key mechanism of immunosuppression. The inhibitory effect of PD-1 on $T$ cells results in their exhaustion, similarly to premature cellular senescence. Both senescent and exhausted T cells do not express the CD28 protein, which is unvaluable for antigenic activation of cells and production of cytokines $[3,5,6]$. In addition, the interaction of PD- 1 with the PD-L1 ligand promotes the differentiation of CD4+ T cells into regulatory FOXP3+ cells, which affects the duration and strength of the immune response [3]. The immunosuppressive activity of PD- 1 is also associated with an inhibitory effect on kinases involved in T-cell activation via SHP-1 and SHP-2 phosphatases, thus inhibiting the T-cell receptor (TCR)-linked PI3K/AKT pathway $[5,7,8]$. The PD-L1 molecule is a ligand for two receptors, B7-1 (CD80) and PD-1 (CD279), and is expressed on T- and B-lymphocytes, macrophages, dendritic cells, endothelial, hematopoietic and epithelial cells [9]. Factor PD-L2, a member of the B7 protein family, has a limited expression on dendritic cells and activated macrophages, and binds mainly to the PD-1 receptor. The PD-1 receptor is known to play a key role in the regulation of reactions in autoimmunity, tumor immunity, transplant immunity, and immunopathology $[3,4,6,9]$. Studying the role of the PD-1 receptor system in the development of immunosuppression in various non-neoplastic con- 
ных клетках и активированных макрофагах и связывается, главным образом, с $\mathrm{PD}-1$ рецептором. Известно, что рецептор PD-1 играет одну из ключевых ролей в регуляции аутоиммунных реакций опухолевого иммунитета, трансплантационного иммунитета, иммунопатологии [3, 4, 6, 9]. Интерес представляет изучение роли системы $\mathrm{PD}-1$ рецептора в развитии иммуносупрессии при различной неонкологической патологии у пациентов в критическом состоянии, а также поиск возможных путей коррекции данного состояния. Кроме того, молекулы PD-1/PD-L1 рассматриваются в качестве потенциальных биомаркеров [10-12].

Цель исследования -оценить активность системы негативной регуляции Т-клеточного ответа у больных пневмониями на фоне гриппа A/H1N1.

\section{Материал и методы}

Обследовали 85 больных пневмонией на фоне гриппа A/H1N1. Из них 30 пациентов с тяжелой пневмонией, $55-$ с нетяжелой пневмонией. Пациенты находились на стационарном лечении в период подъема заболеваемости гриппом А/H1N1 в 2019 г. Исследование проведено с соблюдением принципов Хельсинской декларации Всемирной медицинской ассоциации (WMA Declaration of Helsinki, 1964, ред. 2013 г.) и одобрено локальным этическим комитетом ФГБОУ ВО «Читинская государственная медицинская академия» Минздрава России. Возраст пациентов составил $48 \pm 15$ лет. Мужчины составляли $47,8 \%$, а женщины - 52,2\%. Критериями исключения являлись: нестабильная гемодинамика, ИМТ >30, сахарный диабет, ВИЧ, туберкулез, онкопатология. Группу контроля сформировали из 15 здоровых доноров. Диагноз грипп A/H1N1 подтверждался положительным результатом ПЦР-анализа. Для диагностики и оценки тяжести пневмоний использовали шкалы CURB/CRB-65; SMART-COP, а также Федеральные клинические рекомендации МЗ РФ «Внебольничная пневмония у взрослых", 2019 г. и критерии IDSA/ATS (при наличии одного «большого» или трех «малых» критериев пневмония расценивалась как «тяжелая»).

Стандартная схема терапии включала: Озельтамивир 75 мг 1 т 2 раза в сутки; антибактериальную терапию: при нетяжелом течении - цефалоспорин III поколения (Цефтриаксон/Цефатоксим) 2,0-3,0 г/сутки; при тяжелом течении - комбинацию ингибитор-защищенного пенициллина/цефалоспорина (Амоксициллин/клавуланат 3,6 г/сутки либо Цефоперазон/сульбактам 4,0-6,0 г/сутки) с респираторным фторхинолоном (Левофлоксацин 0,5-1,0 г в сутки/Моксифлоксацин 0,4 г/сутки); инфузионная терапия сбалансированными изотоническими кристаллоидными растворами, антикоагулянтная терапия низкомолекулярными гепаринами в профилактической дозе, при тяжелом течении - контролируемая оксигенотерапия/респираторная поддержка с подбором режима и параметров вентиляции.

Методом проточной цитофлуометрии на анализаторе Beckman Coulter (США), используя набор ditions in critically ill patients and searching for possible ways to correct these conditions appears particularly interesting. In addition, PD-1/PD-L1 molecules are considered to be potential biomarkers [10-12].

The aim of the study - to examine the activity of system of negative regulation of T-cell response in pneumonia patients with the underlying influenza A (H1N1).

\section{Materials and Methods}

85 patients with pneumonia and underlying influenza A $(\mathrm{H} 1 \mathrm{~N} 1)$ were examined. Among them there were 30 patients with severe pneumonia, 55 patients with non-severe pneumonia. The patients were hospitalized during the period of increased influenza A (H1N1) activity in 2019. The study was conducted in compliance with the principles of the World Medical Association (WMA Declaration of Helsinki, 1964, ed. 2013) and was approved by the local ethical committee of the Federal State Budgetary Educational Institution of Higher Professional Education «Chita State Medical Academy» of the Russian Ministry of Health. The age of the patients was $48 \pm 15$ years. Males comprised $47.8 \%$ and females constituted $52.2 \%$ of participants. The exclusion criteria were unstable hemodynamic parameters, BMI $>30$, diabetes mellitus, HIV, tuberculosis, neoplastic conditions. Fifteen healthy donors comprised the control group. The diagnosis of influenza A (H1N1) was confirmed by a positive PCR assay. To assess the pneumonia severity, CURB/CRB-65, SMART-COP scores, as well as Federal clinical guidelines of the Ministry of Health of the Russian Federation on community-acquired pneumonia in adults (2019) and IDSA/ATS criteria (if one «major» or three «minor» criteria were present, pneumonia was considered as «severe») were used.

The standard therapy regimen included antiviral Oseltamivir $75 \mathrm{mg} 1$ tablet 2 times a day. Antibacterial therapy including $3^{\text {rd }}$ generation cephalosporin (Ceftriaxone/Cefotaxim 2.0-3.0 g/day) in mild cases or a combination of penicillin (cephalosporin) with a betalactamase inhibitor (Amoxicillin/clavulanate $3.6 \mathrm{~g} / \mathrm{day}$ or Cefoperazone/Sulbactam 4.0-6.0 g/day) with a respiratory fluoroquinolone (Levofloxacin $0.5-1.0 \mathrm{~g} / \mathrm{day}$ or Moxifloxacin $0.4 \mathrm{~g} /$ day) was administered as a part of standard therapy. Fluid therapy with balanced isotonic crystalloid solutions, anticoagulation therapy with low molecular weight heparin in a prophylactic dose, and controlled oxygen therapy / respiratory support with adjusting mode and parameters of ventilation were also used.

The plasma levels of PD-1, PD-L1, and PD-L2 molecules were determined by flow cytometry on a Beckman Coulter analyzer (USA) using a LEGENDplex $^{\mathrm{TM}}$ HU Immune Checkpoint Panel 1 multiplex assay kit by Biolegend (USA). Statistical analysis was performed using Microsoft Excel and Statistica 10 software. The data were presented as median $(M e)$ and interquartile range (Q1 and $Q 3)$. Normality of data distribution was assessed using Shapiro-Wilk test. To assess significance of differences between the study groups we used Kruskal-Wallis test and Mann-Whitney test for pairwise comparison of the groups, using Bonferroni correction for $P$-value estimation. 
Концентрация исследуемых параметров у больных пневмониями на фоне гриппа А/H1N1 (Me (Q1; Q3)). The levels of studied parameters in patients with pneumonia and underlying influenza A (H1N1) (Me (Q1; Q3)).

\begin{tabular}{|c|c|c|c|}
\hline \multirow[t]{2}{*}{ Parameter } & \multicolumn{3}{|c|}{ Values, pg/ml } \\
\hline & $\begin{array}{c}\text { Control, } \\
n=15\end{array}$ & $\begin{array}{c}\text { Patients with non-severe } \\
\text { pneumonia, } n=55\end{array}$ & $\begin{array}{c}\text { Patients with severe } \\
\text { pneumonia, } n=30\end{array}$ \\
\hline$\overline{\mathrm{PD}}-1$ & $5.69(4.21 ; 7.05)$ & $13.37(3.46 ; 36.19)$ & $26.43(10.11 ; 78.08)$ \\
\hline & & $P=0.03$ & $P<0.001 ; P_{1}=0.02$ \\
\hline$\overline{\mathrm{PD}-\mathrm{L} 1}$ & $9.87(6.84 ; 12.20)$ & $66.02(36.24 ; 117.58)$ & $105.18(50.34 ; 273.47)$ \\
\hline & & $P<0.001$ & $P<0.001 ; P_{1}=0.008$ \\
\hline PD-L2 & $6658.00(4891.50 ; 8064.00)$ & $\begin{array}{c}15038.50(11957.25 ; 18335.50) \\
P<0.001\end{array}$ & $\begin{array}{c}14854.50(10961.50 ; 18331.50) \\
P<0.001 ; P_{l}=0.53\end{array}$ \\
\hline
\end{tabular}

Note. $P$ - significance of differences compared with the healthy controls; $P_{1}-$ significance of differences between the group of patients with non-severe pneumonia and the group of patients with severe pneumonia.

Примечание. Values - значения; patients with non-severe/severe pneumonia - пациенты с нетяжелой/тяжелой пневмонией. $p$ - статистическая значимость различий по сравнению со здоровыми; $p_{1}$ - статистическая значимость различий между группой пациентов с нетяжелой пневмонией и группой пациентов с тяжелой пневмонией.

для мультиплексного анализа LEGENDplex ${ }^{\mathrm{TM}} \mathrm{HU}$ Immune Checkpoint Panel 1 фирмы Biolegend (США), определяли концентрацию молекул PD-1, PD-L1, PD-L2 в плазме. Статистический анализ выполняли с помощью пакета программ Microsoft Excel и Statistica 10. Данные представили в виде медианы $(M e)$ и интерквартильного интервала (Q1 и Q3). Оценку нормальности распределения данных осуществлялис помощью критерия Шапиро-Уилка. Для оценки статистической значимости различий между исследуемыми группами использовали критерий Краскела-Уоллиса, а также критерий Манна-Уитни, при попарном сравнении групп, с применением поправки Бонферрони при оценке значения $p$.

\section{Результаты и обсуждение}

При исследовании иммунной контрольной точки PD-1 установили, что у больных нетяжелой пневмонией на фоне гриппа A/H1N1 концентрация PD-1 увеличивалась в 2,3 раза по сравнению с контрольной группой и составляла 13,37 $(3,46 ; 36,19)$ пг/мл $(p=0,03)$. Выявили, что у больных тяжелой пневмонией на фоне гриппа A/H1N1 концентрация PD-1 увеличивалась в $4,6$ раза ( $p<0,001)$ по сравнению с контрольной группой и составляла $26,43(10,11 ; 78,08)$ пг/мл (табл.). При этом, у больных нетяжелой пневмонией на фоне гриппа A/H1N1 концентрация PD1 оказалась в 1,9 раза ниже относительно пациентов с тяжелой пневмонией $(p=0,02)$.

При исследовании лиганда иммунной контрольной точки PD-1 - PD-L1 установили, что у больных нетяжелой пневмонией на фоне гриппа A/H1N1 содержание PD-L1 было выше в 6,6 раза по сравнению со здоровыми и составляло 66,02 $(36,24 ; 117,58)$ пг/мл ( $p<0,001)$. Оказалось, что у больных тяжелой пневмонией на фоне гриппа A/H1N1 концентрация PD-L1 увеличивалась в 10,6 раза ( $p<0,001)$ и составляла 105,18 (50,34; 273,47) пг/мл (табл.). Также выявили, что у больных тяжелой пневмонией на фоне гриппа A/H1N1 концентрация PD-L1 увеличивалась в 1,6 раза относительно больных нетяжелой пневмонией $(p=0,008)$.

\section{Results and Discussion}

When studying the immune checkpoint PD-1 we found that in patients with non-severe pneumonia with underlying influenza A (H1N1) the PD-1 concentration increased 2,3-fold compared to the control group and was $13,37(3,46 ; 36,19) \mathrm{pg} / \mathrm{ml}$ $(P=0,03)$. Patients with severe pneumonia and underlying influenza A (H1N1) showed a 4.6-fold $(P<0.001)$ increase in PD-1 concentration compared to the control group, amounting to 26.43 $(10.11 ; 78.08) \mathrm{pg} / \mathrm{ml}$ (table). At the same time, PD- 1 concentration was 1.9 times lower in patients with non-severe pneumonia and influenza A (H1N1) compared to patients with severe pneumonia $(P=0.02)$.

While studying the PD-1 immune checkpoint ligand, PD-L1, we found that in patients with nonsevere pneumonia and influenza A (H1N1), PD-L1 level was 6.6 times higher compared to the healthy controls and was $66.02(36.24 ; 117.58) \mathrm{pg} / \mathrm{ml}$ $(P<0.001)$. In patients with severe pneumonia and influenza A (H1N1), the PD-L1 level increased 10.6fold $(P<0.001)$ and was $105.18(50.34 ; 273.47) \mathrm{pg} / \mathrm{ml}$ (table). We also found that patients with severe pneumonia with underlying influenza A (H1N1) had a 1.6-fold increase in PD-L1 level vs the patients with non-severe pneumonia $(P=0.008)$.

Quantification of the PD-1-PD-L2 immune checkpoint ligand revealed that in patients with non-severe pneumonia and underlying influenza A (H1N1) the PD-L2 level increased 2.2fold compared to the healthy controls and was $15,038.50(11,957.25 ; 18,335.50) \mathrm{pg} / \mathrm{ml}(P<0.001)$ We found that in patients with severe pneumonia and underlying influenza A (H1N1) the PDL2 concentration increased 2.2-fold compared to the healthy controls and was $14,854.50$ $(10,961.50 ; 18,331.50) \mathrm{pg} / \mathrm{ml}(P<0.001)$ (Table). At the same time, no differences in PD-L2 level between patients with severe and non-severe pneumonia with underlying influenza A (H1N1) were found $(P=0.53)$. 
При количественном определении лиганда иммунной контрольной точки PD-1 - PD-L2 выявили, что у больных нетяжелой пневмонией на фоне гриппа A/H1N1 содержание PD-L2 увеличивалось в 2,2 раза относительно здоровых и составляло 15038,50 (11957,25; 18335,50) пг/мл ( $p<0,001)$ Установили, что у больных тяжелой пневмонией на фоне гриппа A/H1N1 концентрация PD-L2 увеличивалась в 2,2 раза относительно здоровых и составляла 14854,50 $(10961,50 ; 18331,50)$ пг/мл ( $p<0,001)$ (табл.). При этом различий в концентрации PD-L2 у больных тяжелой и нетяжелой пневмонией на фоне гриппа A/H1N1 не выявили $(p=0,53)$.

C момента первой формулировки определения синдрома системного воспалительного ответа (SIRS), а также компенсаторного противовоспалительного синдрома (CARS) R. Bone прошло, практически, три десятилетия. За этот период накоплен большой опыт как в изучении патогенеза, так и в интенсивной терапии критических состояний $[1,2]$. Кроме того, достижения молекулярной биологии, молекулярной генетики, иммунологии, патологической физиологии сделали взгляд на проблему органной дисфункции значительно шире. Раскрыты различные механизмы влияния на макроорганизм систем рецепторов, участвующих в реализации реакций врожденного и адаптивного иммунитета, вследствие повреждения или инфекции $[1,13,14]$. Одной из таких систем является система негативной регуляции Т-клеточных ответов, рецептора PD-1 и его лигандов PD-L1 и PD-L2 [3, 9, 15, 16]. Роль PD-1 на клинической модели сепсиса впервые описана X. Huang и коллегами. Так, у нокаутных по PD-1 мышей исследователями продемонстрированы увеличение выживаемости, улучшение бактериального клиренса и умеренное органное повреждение на 7-е сутки, причем не было зафиксировано ни одного летального исхода в течение первых 4-х суток. Исследование подтвердило, что дефицит PD-1 способствует эффективной защите мышей от раннего летального исхода при сепсисе [3, 17]. Увеличение выживаемости при сепсисе также наблюдалось у мышей, дефицитных по PD-L1 [3, 7]. Кроме того, показано увеличение уровня экспрессии PD-1 CD4+ и CD8+ T-клетками и PD-L1 моноцитами у септических пациентов [16-20]. Другая группа исследователей наблюдала увеличение экспрессии рецептора PD-1 CD4+ T-клетками и уменьшение разнообразия Т-клеточного рецептора у пациентов на ранних стадиях септического шока $[3,20,21]$.

Мы зафиксировали статистически значимое увеличение концентрации PD-1 и его лигандов PD-L1 и PD-L2 у больных пневмонией на фоне гриппа A/H1N1, ассоциированное с
Almost three decades have passed since the first definition of the systemic inflammatory response syndrome (SIRS) and the compensatory anti-inflammatory syndrome (CARS) was formulated by R. Bone. During this period a lot of experience has been accumulated both in the study of pathogenesis and intensive therapy of critical conditions $[1,2]$. In addition, advances in molecular biology, molecular genetics, immunology, pathological physiology have led to a much broader view of the problem of organ dysfunction. Various mechanisms of effects of receptor systems participating in the innate and adaptive immunity reactions caused by damage or infection have been uncovered $[1,13$, 14]. One such system is the negative regulation of T-cell responses, the PD- 1 receptor and its ligands PD-L1 and PD-L2 [3, 9, 15, 16]. The role of PD-1 in a clinical model of sepsis was first described by X. Huang and colleagues. Thus, in PD-1 knockout mice, the researchers demonstrated increased survival, improved bacterial clearance and moderate organ damage by day 7 , and no deaths were reported during the first 4 days. The study confirmed that PD-1 deficiency contributes to the effective protection of mice against early mortality in sepsis $[3,17]$. Increased survival in sepsis was also observed in PD-L1-deficient mice [3, 7]. In addition, increased levels of PD-1 expression by CD4+ and CD8+ T cells and PD-L1 monocytes in septic patients have been shown [16-20]. Another group of investigators observed an increase in $\mathrm{PD}-1$ receptor expression by CD4+ T cells and a decrease in T-cell receptor diversity in patients in the early stages of septic shock [3, 20, 21].

We observed significant increase in the levels of PD- 1 and its ligands PD-L1 and PD-L2 in patients with pneumonia with underlying influenza A (H1N1), associated with the severity of disease. The increase of PD-1 concentration, in our opinion, reflects the involvement of negative immunological regulators in the systemic inflammatory response with the initiation of a compensatory anti-inflammatory response, when immunosuppression is not yet pronounced, however, active mechanisms are included in the process, which fits into the concept of systemic inflammation according to R. Bone. In addition, a marked increase in PD-L1 ligand level, especially in patients with severe pneumonia, indicates the activation of inhibitory co-stimulatory molecules, since PD-L1 is the ligand of two receptors, B7- 1 and PD- $[9,22,23]$. At the same time, an increase in the concentration of PD-L2, which is a PD-1 ligand, may indicate the transition of the immune reaction cascade to the anti-inflammatory phase $[5,6,9]$.

Currently, the immunological cascade of proand anti-inflammatory reactions is studied in detail in critically ill patients with severe and extremely severe COVID-19 [24, 25]. This allows to identify in- 
тяжестью состояния. Увеличение концентрации PD-1, на наш взгляд, отражает вовлечение в процесс системного воспалительного ответа негативных иммунологических регуляторов с инициацией компенсаторного противовоспалительного ответа, когда иммуносупрессия еще не выражена, однако активные механизмы включаются в процесс, что вписывается в концепцию системного воспаления R. Bone. Кроме того, выраженное увеличение концентрации лиганда PD-L1, особенно у пациентов с тяжелой пневмонией, свидетельствует об активации ингибирующих ко-стимулирующих молекул, поскольку PD-L1 является лигандом двух рецепторов - B7-1 и PD-1 [9, 22, 23]. При этом увеличение концентрации PD-L2, являющегося лигандом PD-1, может свидетельствовать о переходе каскада иммунных реакций в противовоспалительную фазу [5, 6, 9].

На сегодняшний день клинически иммунологический каскад про- и противовоспалительных реакций подробно изучается на модели пациентов с тяжелым и крайне тяжелым течением COVID-19, находящихся в критическом состоянии $[24,25]$. Это обстоятельство позволяет определять показания и эффективно применять на практике генно-инженерные лекарственные средства - ингибиторы янускиназ и цитокиновых рецепторов, антицитокиновые препараты, блокируя дизрегуляцию иммунной системы, способствуя улучшению результатов лечения и снижению летальности у пациентов, находящихся в критическом состоянии [25-28]. Комплекс рецептора PD-1 с лигандами PD-L1/PD-L2, как мишень для фармакологического воздействия используется при комплексном лечении различной онкопатологии $[15,29]$. Однако, имеются данные, свидетельствующие об эффективности применения моноклональных антител для PD-L1 (Атезолизумаб), снижающего иммуносупрессию на модели сепсиса мышей. Исследователи отмечают снижение скорости апоптоза Т-лимфоцитов и увеличение выживаемости [17].

\section{Литература}

1. Гусев Е. Ю., Черешнев В.А. Иммунологические и патофизиологические механизмы системного воспаления. Медицинская иммунология. 2012; 1-2. URL: https: //cyberleninka.ru/article/n/ immunologicheskie-i-patofiziologicheskie-mehanizmy-sistemnogovospaleniya (дата обращения: 02.04.2021)

2. Гусев Е.Ю., Зотова Н.В., Лазарева М.А. Цитокиновый ответ и другие отличительные особенности критических фаз системного воспаления при сепсисе. Медицинская иммунология. 2014 №2. URL: https: //cyberleninka.ru/article/n/tsitokinovyy-otvet-idrugie-otlichitelnye-osobennosti-kriticheskih-faz-sistemnogovospaleniya-pri-sepsise (дата обращения: 02.04.2021)

3. Ханова М.Ю., Григорьев Е.В. Роль рецепторов PD-1 и $\mathrm{PD}-\mathrm{L} 1$ в развитии системного воспалительного ответа и методы иммуноадъювантной терапии. Патология кровообращения и кардиохирургия. 2019; 23 (3): 76-83. DOI: 10.21688/1681-3472-2019-376-83

4. Huang X., Venet F., Wang Y.L., Lepape A., Yuan Z., Chen Y., Swan R., Kherouf H., Monneret G., Chung C.S., Ayala A. PD-1 expression by macrophages plays a pathologic role in altering microbial clearance and dications for effective clinical use the genetically engineered drugs such as Janus kinase, cytokine receptor inhibitors and anti-cytokine drugs, which block immune dysregulation and contribute to improved treatment outcomes and decreased mortality in critically ill patients [25-28]. The PD-1 receptor complex and PD-L1/PD-L2 ligands are established targets for pharmacological drugs employed in comprehensive treatment of various neoplastic diseases $[15,29]$. However, there is evidence that monoclonal antibodies against PD-L1 (Atezolizumab) are effective in reducing immunosuppression in a mouse model of sepsis. Researchers have noted a decrease in the rate of T-lymphocyte apoptosis and an increase in survival [17].

\section{Conclusion}

A significant increase in the concentration of PD- 1 and its ligands PD-L1 and PD-L2 in plasma from patients with influenza $\mathrm{A}(\mathrm{H} 1 \mathrm{~N} 1)$ pneumonia is associated with the severity of disease and demonstrates the involvement of negative regulation of T-cell responses in cascade of immunological reactions.

The correction of immune reactions controlled by PD-1, PD-L1, PD-L2 molecules using monoclonal antibodies could be a promising approach towards developing new treatment modalities for critically ill patients.

\section{Заключение}

Значимое увеличение концентрации PD-1 и его лигандов PD-L1 и PD-L2 в плазме у пациентов пневмонией на фоне гриппа A/H1N1 ассоциируется с тяжестью состояния и свидетельствует о вовлечении в каскад иммунологических реакций системы негативной регуляции Т-клеточного ответа.

Коррекция иммунных реакций, контролируемых молекулами PD-1, PD-L1, PD-L2, с помощью моноклональных антител является перспективным научным направлением, направленным на разработку новых методов лечения пациентов в критических состояниях.

\section{References}

1. Gusev E. Yu., Chereshnev V.A. Immunological and pathophysiological mechanisms of systemic inflammation. Meditsinskaya Immunologiya = Medical Immunology (Russia). 2012; 1-2 [In Russ.]. URL: https: //cyberleninka.ru/article/n/immunologicheskie-ipatofiziologicheskie-mehanizmy-sistemnogo-vospaleniya (date of access: 04/02/2021)

2. Gusev E.Yu., Zotova N.V., Lazareva M.A. Cytokine response and other distinctive features of critical phases of systemic inflammation in sepsis. Meditsinskaya Immunologiya = Medical Immunology (Russia). 2014; 2 [In Russ.]. URL: https: //cyberleninka.ru/article/n/ tsitokinovyy-otvet-i-drugie-otlichitelnye-osobennosti-kriticheskihfaz-sistemnogo-vospaleniya-pri-sepsise (date of access: 04/02/2021)

3. Khanova M.Yu., Grigoryev E.V. Roles of PD-1 and PD-L1 receptors in the development of systemic inflammatory response and immunoadjuvant therapy. Patologiya krovoobrashcheniya $i$ kardiokhirurgiya $=$ Circulation Pathology and Cardiac Surgery. 2019; 23 (3): 76-83. [In Russ.] DOI: 10.21688/1681-3472-2019-3-76-83

4. Huang X., Venet F., Wang Y.L., Lepape A., Yuan Z., Chen Y., Swan R. Kherouf H., Monneret G., Chung C.S., Ayala A. PD-1 expression by 
the innate inflammatory response to sepsis. Proc Natl Acad Sci USA. 2009; 106 (15): 6303-8. PMID: 19332785. DOI: 10.1073/pnas.0809422106

5. $\quad$ Qin W., Hu L., Zhang X., Jiang S., Li J., Zhang Z., Wang X. The Diverse Function of PD-1/PD-L Pathway Beyond Cancer. Front Immunol. 2019; 10: 2298. DOI: 10.3389/fimmu.2019.02298. PMID: 31636634; PMCID: PMC6787287

6. Jubel J.M., Barbati Z.R., Burger C., Wirtz D.C., Schildberg F.A. The Role of PD-1 in Acute and Chronic Infection. Front Immunol. 2020; 11 487. DOI: 10.3389/fimmu.2020.00487. PMID: 32265932; PMCID PMC7105608

7. Саяпина М.С. Иммунорегуляторные функции ингибиторов PD1/PD-L1 и развитие к ним резистентности. Злокачественные опухоли. 2017; (2): 94-99. DOI: 10.18027/2224-5057-2017-2-94-99

8. Zitvogel L., Kroemer G. Targeting PD-1 / PD-L1 interactions for cancer immunotherapy. OncoImmunology. 2012; 1 (8): 1223-1225. PMID: 23243584 PMCID: PMC3518493 DOI: 10.4161/onci.21335

9. Ключагина Ю.И., Соколова З.А., Барышникова М.А. Роль рецептора PD-1 и его лигандов PD-L1 и PD-L2 в иммунотерапии опухолей. Онкопедиатрия. 2017; 4 (1): 49-55. DOI: 10.15690/onco.v4i1.1684

10. Wilson J.K., Zhao Y., Singer M., Spencer J., Shankar-Hari M. Lymphocyte subset expression and serum concentrations of PD-1/ PD-L1 in sepsis pilot study. Crit Care. 2018; 22 (1): 95. DOI: 10.1186/s13054-018-2020-2

11. Yu X., Pan Y., Fei Q., Lin X., Chen Z., Huang H. Serum soluble PD-1 plays a role in predicting infection complications in patients with acute pancreatitis. Immun Inflamm Dis. 2021; 9 (1): 310-318. Epub 2021 Jan 8. DOI: 10.1002/iid3.394. PMID: 33417300; PMCID: PMC7860599

12. Zhao Y., Jia Y., Li C., Shao R., Fang Y. Predictive Value of Soluble Programmed Death-1 for Severe Sepsis and Septic Shock During the First Week in an Intensive Care Unit. Shock. 2019; 51 (3): 289-297. DOI: 10.1097/SHK.0000000000001171. PMID: 29702526

13. Терехов И.В., Хадариев А.А., Бондарь С.С., Воеводин А.А. Экспрессия toll- и nod-подобных рецепторов, уровень в мононуклеарных клетках цельной крови регуляторных факторов противовирусной защиты и продукция интерферона под влиянием низкоинтенсивного микроволнового излучения частотой 1 ГГц. Вестник новых медицинских технологий. Электронное из дание. 2016; 3: 2-22. URL: http: //www.medtsu.tula.ru/VNMT/ Bulletin/E2016-3/2-22.pdf (дата обращения: 17.09.2016). DOI: $12737 / 21557$

14. Wang H., Wei Y., Zeng Y., Qin Y., Xiong B., Qin G., Li J., Hu D., Qiu X, Sooranna S.R., Pinhu L. The association of polymorphisms of TLR4 and CD14 genes with susceptibility to sepsis in a Chinese population. BMC Medical Genetics. 2014; 15: 123. PMID: 25394369 PMCID: PMC4411696 DOI: 10.1186/s12881-014-0123-4

15. Матвеев В.Б., Киричек А.А., Сафронова В.М., Кокосадзе Н.В., Халмурзаев О.А., Камолов Б.Ш., Любченко Л.Н. Прогностическое значение PD-L1-статуса опухоли у больных метастатическим раком предстательной железы. Онкоурология. 2019; 15 (1): 57-65. DOI: 10.17650/1726-9776-2019-15-1-57-65

16. Boomer J.S., To K., Chang K.C., Takasu O., Osborne D.F., Walton A.H. Bricker T.L., Jarman S.D. 2nd, Kreisel D., Krupnick A.S., Srivastava A., Jin HT, Ahmed R, Okazaki T. Role of PD-1 in regulating T-cell immunity. Curr Top Microbiol Immunol. 2011; 350: 17-37. DOI: 10.1007/82 2010_116. PMID: 21061197

17. Chen I., Chen R., Huang S., Zu B., Zhang S. Atezolizumab alleviates the immunosuppression induced by PD-L1-positive neutrophils and improves the survival of mice during sepsis. Mol Med Rep. 2021; 23 (2): 1. DOI: 10.3892/mmr.2020.11783. Epub 2020 Dec 15. PMID: 33655320; PMCID: PMC7751480

18. Li J., Tang Z., Xie M., Hang C., Yu Y., Li C. Association between elevation of plasma biomarkers and monocyte dysfunction and their combination in predicting sepsis: An observational single-centre cohort study. Innate Immun. 2020; 26 (6): 514-527. DOI: 10.1177/1753425920926602. Epub 2020 May 26. PMID: 32456597; PMCID: PMC7491234

19. Shao R., Fang Y., Yu H., Zhao L., Jiang Z., Li C.S. Monocyte programmed death ligand-1 expression after 3-4 days of sepsis is associated with risk stratification and mortality in septic patients: a prospective cohort study. Crit Care. 2016; 20 (1): 124. PMID: 27156867. DOI: 10.1186/s13054-016-1301-x

20. Tomino A., Tsuda M., Aoki R., Kajita Y., Hashiba M., Terajima T., Kano $H$., Takeyama $N$. Increased PD-1 expression and altered T cell repertoire diversity predict mortality in patients with septic shock: a preliminary study. PLoS One. 2017; 12 (1): e0169653. PMID: 28072859. DOI: 10.1371 /journal pone. 0169653

21. Swanson P.E., Green J.M., Hotchkiss R.S. Immunosuppression in patients who die of sepsis and multiple organ failure. JAMA. 2011; 306 (23): 2594-2605. PMID: 22187279. DOI: 10.1001/ jama.2011.1829

22. Chang K., Svabek C., Vazquez-Guillamet C., Sato B., Rasche D., Wilson S., Robbins P., Ulbrandt N., Suzich J.A., Green J., Patera A.C., Blair W., Krishnan S.,. Hotchkiss R. Targeting the programmed cell death 1: programmed cell death ligand 1 pathway reverses $T$ cell exhaustion in patients with sepsis. Crit Care. 2014; 18 (1): R3. PMID: 24387680. DOI: $10.1186 / \mathrm{cc} 13176$

23. Huang X., Chen Y., Chung C.S., Yuan Z., Monaghan S.F., Wang F., Ayala A. Identification of B7-H1 as a novel mediator of the innate macrophages plays a pathologic role in altering microbial clearance and the innate inflammatory response to sepsis. Proc Natl Acad Sci USA 2009; 106 (15): 6303-8. PMID: 19332785. DOI: 10.1073/pnas.0809422106

5. Qin W., Hu L., Zhang X., Jiang S., Li J., Zhang Z., Wang X. The Diverse Function of PD-1/PD-L Pathway Beyond Cancer. Front Immunol. 2019; 10: 2298. DOI: 10.3389/fimmu.2019.02298. PMID: 31636634; PMCID: PMC6787287

6. Jubel J.M., Barbati Z.R., Burger C., Wirtz D.C., Schildberg F.A. The Role of PD-1 in Acute and Chronic Infection. Front Immunol. 2020; 11: 487. DOI: 10.3389/fimmu.2020.00487. PMID: 32265932; PMCID: PMC7105608

7. Sayapina M.S. Immunoregulatory functions of PD-1/PD-L1 inhibitors and development of resistance to them. Malignant tumours. 2017; (2): 94-99. [In Russ.] DOI: 10.18027/2224-5057-20172-94-99

8. Zitvogel L., Kroemer G. Targeting PD-1 / PD-L1 interactions for cance immunotherapy. OncoImmunology. 2012; 1 (8): 1223-1225. PMID: 23243584 PMCID: PMC3518493 DOI: 10.4161/onci.21335

9. Klyuchagina Yu.I., Sokolova Z.A., Baryshnikova M.A. Role of PD1 Receptor and its Ligands PD-L1 and PD-L2 in Cancer Immunotherapy. Oncopediatria. 2017; 4 (1): 49-55. [In Russ.]. DOI 10.15690 / onco.v4il.1684

10. Wilson J.K., Zhao Y., Singer M., Spencer J., Shankar-Hari M. Lymphocyte subset expression and serum concentrations of PD-1/ PD-L1 in sepsis - pilot study. Crit Care. 2018; 22 (1): 95. DOI: 10.1186/s13054-018-2020-2

11. Yu X., Pan Y., Fei Q., Lin X., Chen Z., Huang H. Serum soluble PD-1 plays a role in predicting infection complications in patients with acute pancreatitis. Immun Inflamm Dis. 2021; 9 (1): 310-318. Epub 2021 Jan 8. DOI: 10.1002/iid3.394. PMID: 33417300; PMCID: PMC7860599

12. Zhao Y., Jia Y, Li C., Shao R., Fang $Y$. Predictive Value of Soluble Programmed Death- 1 for Severe Sepsis and Septic Shock During the First Week in an Intensive Care Unit. Shock. 2019; 51 (3): 289-297. DOI: 10.1097/SHK.0000000000001171. PMID: 29702526

13. Terekhov I.V., Khadartsev A.A., Bondar S.S., Voevodin A.A. Expression The Toll- And Nod-Like Receptors, The Levels In Mononuclear Cells Whole Blood, Regulatory Factors Of Antiviral Defense And Interferon Production Product Under The Influence Of Low-Intensity Microwave Radiation With A Frequency Of 1 Ghz. Journal of New Medical Technologies, eEdition. 2016. No. 3. Publication 2-22. [In Russ.] URL: http: //www.medtsu.tula.ru/VNMT/Bulletin/E2016-3/222.pdf (date accessed: 17.09.2016). DOI: $12737 / 21557$

14. Wang H., Wei Y., Zeng Y., Qin Y., Xiong B., Qin G., Li J., Hu D., Qiu X., Sooranna S.R., Pinhu L. The association of polymorphisms of TLR4 and CD14 genes with susceptibility to sepsis in a Chinese population. BMC Medical Genetics. 2014; 15: 123. PMID: 25394369 PMCID: PMC4411696 DOI: 10.1186/s12881-014-0123-4

15. Matveev V.B., Kirichek A.A., Safronova V.M., Kokosadze N.V., Khalmurzaev O.A., Kamolov B.Sh., Lyubchenko L.N. Prognostic value of PD-L1 tumor status in patients with metastatic prostate cancer. Onkourologiya=Cancer Urology. 2019; 15 (1): 57-65. [In Russ.]. DOI: 10.17650/1726-9776-2019-15-1-57-65

16. Boomer J.S., To K., Chang K.C., Takasu O., Osborne D.F., Walton A.H., Bricker T.L., Jarman S.D. 2nd, Kreisel D., Krupnick A.S., Srivastava A. Jin HT, Ahmed R, Okazaki T. Role of PD-1 in regulating T-cell immunity. Curr Top Microbiol Immunol. 2011; 350: 17-37. DOI: 10.1007/82_2010_116. PMID: 21061197

17. Chen J., Chen R., Huang S., Zu B., Zhang S. Atezolizumab alleviates the immunosuppression induced by PD-L1-positive neutrophils and improves the survival of mice during sepsis. Mol Med Rep. 2021; 23 (2): 1. DOI: 10.3892/mmr.2020.11783. Epub 2020 Dec 15. PMID: 33655320; PMCID: PMC7751480

18. Li J., Tang Z., Xie M., Hang C., Yu Y., Li C. Association between elevation of plasma biomarkers and monocyte dysfunction and their combination in predicting sepsis: An observational single-centre cohort study. Innate Immun. 2020; 26 (6): 514-527. DOI 10.1177/1753425920926602. Epub 2020 May 26. PMID: 32456597; PMCID: PMC7491234

19. Shao R., Fang Y., Yu H., Zhao L., Jiang Z., Li C.S. Monocyte programmed death ligand-1 expression after 3-4 days of sepsis is associated with risk stratification and mortality in septic patients: a prospective cohort study. Crit Care. 2016; 20 (1): 124. PMID: 27156867. DOI: 10.1186/s13054-016-1301-x

20. Tomino A., Tsuda M., Aoki R., Kajita Y., Hashiba M., Terajima T., Kano H., Takeyama $N$. Increased PD-1 expression and altered T cell repertoire diversity predict mortality in patients with septic shock: a preliminary study. PLoS One. 2017; 12 (1): e0169653. PMID: 28072859. DOI: 10.1371/journal.pone.0169653

21. Swanson P.E., Green J.M., Hotchkiss R.S. Immunosuppression in patients who die of sepsis and multiple organ failure. JAMA. 2011 306 (23): 2594-2605. PMID: 22187279. DOI: 10.1001/ jama 2011.1829

22. Chang K., Svabek C., Vazquez-Guillamet C., Sato B., Rasche D., Wilson S., Robbins P., Ulbrandt N., Suzich J.A., Green J., Patera A.C., Blair W., Krishnan S.,. Hotchkiss R. Targeting the programmed cell death 1: programmed cell death ligand 1 pathway reverses $T$ cell exhaustion in patients with sepsis. Crit Care. 2014; 18 (1): R3. PMID: 24387680. DOI: $10.1186 / \operatorname{cc} 13176$ 
immune/proinflammatory response as well as a possible myeloid cell prognostic biomarker in sepsis. I Immunol. 2014; 192 (3): 1091-1099. PMID: 24379123. DOI: 10.4049/jimmunol.1302252

24. Временные методические рекомендации Минздрава России «Профилактика, диагностика и лечение новой коронавирусной инфекции (COVID-19)». https: //static-0.minzdrav.gov.ru/ system/attachments/attaches/000/054/669/original/\%D0\%98\%D0 \%BD\%D1\%84\%D0\%BE\%D0\%B3\%D1\%80\%D0\%B0\%D1\%84\%D0\%B 8\%D0\%BA\%D0\%B0_COVID-19_v10.pdf

25. Смирнов В.С., Тотолян А.А. Некоторые возможности иммунотерапии при коронавирусной инфекции. Инфекция и иммуниmem. 2020; 10 (3): 446-458.

26. Насонов Е.Л. Коронавирусная болезнь-2019 (COVID-19): значение ингибиторов IL-6. Пульмонология. 2020; 30 (5): 629-644. DOI: 10.18093/0869-0189-2020-30-5-629-644

27. Сташкив В.И., Замятина К.А., Шантаревич М.Ю., Никитина И. В., Кармазановский Г.Г., Ревишвили А.Ш. КТ-семиотика пневмонии у пациентов с COVID-19, получающих терапию тоцилизумабом: обзор зарубежной литературы. Медицинская визуализаиия. 2020; 24 (2): 96-97. DOI: 10.24835/1607-0763-2020-2-96-97

28. Безопасность применения ремдесивира и тоцилизумаба при лечении COVID-19. Безопасность и риск фармакотерапии. 2020; 8 (3): 160-162. DOI: 10.30895/2312-7821-2020-8-3-160-162

29. Андрусова Н.Н., Колганова М.А., Алешина А.В., Шохин И.Е. PD-L1 как потенциальная мишень в противораковой терапии (обзор). Разработка и регистрация лекарственных средств. 2021; 10 (1): 31-36. DOI: 10.33380/2305-2066-2021-10-1-31-36

Поступила 24.05.21
23. Huang X., Chen Y., Chung C.S., Yuan Z., Monaghan S.F., Wang F., Ayala A. Identification of B7-H1 as a novel mediator of the innate immune/proinflammatory response as well as a possible myeloid cell prognostic biomarker in sepsis. J Immunol. 2014; 192 (3): 10911099. PMID: 24379123. DOI: 10.4049/jimmunol.1302252

24. Interim guidelines of the Ministry of Health of Russia «Prevention diagnosis and treatment of new coronavirus infection (COVID-19). [In Russ.] Https: //static-0.minzdrav.gov.ru/system/attachments/ attaches/000/054/669/original/\%D0\%98\%D0\%BD\%D1\%84\% D0\%BE\%D0\%B3\%D1\%80\%D0\%B0\%D1\%84\%D0\%B8\%D0\%BA\%D0 \%B0_COVID-19_v10.pdf

25. Smirnov V.S., Totolyan A.A. Some possibilities of immunotherapy for coronavirus infection. Infektsiya i immunitet= Russian Journal of Infection and Immunity. 2020; 10 (3): 446-458. [In Russ.]. DOI: 10.15789 / 2220-7619-SPO-1470

26. Nasonov E.L. Coronavirus Disease 2019 (COVID-19): The Importance of IL-6 Inhibitors. Pul'monologiya. 2020; 30 (5): 629-644 [In Russ.]. DOI: 10.18093 / 0869-0189-2020-30-5-629-644

27. Stashkiv V.I., Zamyatina K.A., Shantarevich M.Yu., Nikitina I.V. Karmazanovsky G.G., Revishvili A.S. CT findings in patients with COVID-19 pneumonia after treatment with tocilizumab: foreign literature review. Meditsinskaya vizualizatsiya=Medical Visualization 2020; 24 (2): 96-97. [In Russ.]. DOI: 10.24835/1607-0763-2020-2-96-97

28. Safety of Remdesivir and Tocilizumab in COVID-19 Treatment Bezopasnost' $i$ risk farmakoterapii = Safety and Risk of Pharmacotherapy. 2020; 8 (3): 160-162. [In Russ.]. DOI: 10.30895/23127821-2020-8-3-160-162

29. Andrusova N.N., Kolganova M.A., Aleshina A.V., Shohin I.E. PD-L1 as a Potential Target in Cancer Therapy (Review). Drug development \& registration. 2021; 10 (1): 31-36. [In Russ.] DOI: 10.33380/2305-20662021-10-1-31-36

Received 24.05.21 